\title{
Profile of the Population Cared for in a Referral Emergency Unit
}

\author{
Gabriella Novelli Oliveira ${ }^{1}$ \\ Michele de Freitas Neves Silva ${ }^{2}$ \\ Izilda Esmenia Muglia Araujo ${ }^{3}$ \\ Marco Antonio Carvalho Filho ${ }^{4}$
}

\begin{abstract}
Acquiring knowledge concerning the characteristics of the population that seeks an emergency department can support the planning of health actions. This study identifies the socio-demographic profile and the main complaints of the adult population cared for in a Referral Emergency Unit (RECU). This descriptive and retrospective study was conducted in the RECU of a university hospital in the State of Sao Paulo, Brazil. The sample was composed of the service's care forms generated for the period between January and December 2008. The instrument was based on data contained in the care forms. Young women (14 to 54 years old), residents of neighborhoods near the RECU, spontaneously sought the service during the week from $7 \mathrm{am}$ to $7 \mathrm{pm}$. The most frequent complaints were headache, back pain, abdominal and chest pain. The conclusion is that most of the sample was young adults, of productive age, female, who spontaneously sought the service on weekdays during the day. Most complaints were of low complexity.
\end{abstract}

Descriptors: Emergency Medical Services; Health Profile; Emergency Nursing.

\footnotetext{
${ }^{1}$ Nursing undergraduate student, Departamento de Enfermagem, Faculdade de Ciências Médicas, Universidade Estadual de Campinas (Unicamp), SP, Brazil. E-mail: novellioliveira@gmail.com.

${ }^{2}$ RN, Master's Student, Departamento de Enfermagem, Faculdade de Ciências Médicas, Universidade Estadual de Campinas (Unicamp), SP, Brasil. E-mail: michelefneves@hotmail.com.

${ }^{3}$ RN, Ph.D. in Medical Sciences, Professor, Departamento de Enfermagem, Faculdade de Ciências Médicas, Universidade Estadual de Campinas (Unicamp), SP, Brazil. E-mail: iema@fcm.unicamp.br.

${ }^{4}$ Physician, Ph.D. in Medical Clinic, Professor, Departamento de Clinica Médica, Faculdade de Ciências Médicas, Universidade Estadual de Campinas (Unicamp), SP, Brazil. E-mail: macarvalhofilho@uol.com.br.
}

Corresponding Author:

Gabriella Novelli Oliveira

Universidade Estadual de Campinas. Faculdade de Ciências Médicas

Departamento de Enfermagem

Rua Tessália Vieira de Camargo, 126

Cidade Universitária "Zeferino Vaz"

CEP: 13084-971 Campinas, SP, Brasil

E-mail: novellioliveira@gmail.com 


\section{Perfil da população atendida em uma unidade de emergência referenciada}

O conhecimento das características da população que frequenta um serviço de emergência constitui ferramenta de planejamento de ações em saúde. O objetivo deste estudo foi identificar o perfil sociodemográfico e as principais queixas da população adulta, atendida na unidade de emergência referenciada (UER). O método usado foi o descritivo/ retrospectivo, desenvolvido na UER de um hospital de ensino no interior do Estado de São Paulo. A amostra ficou constituída pelos boletins de atendimento (BAU), referentes ao período de janeiro a dezembro/2008. O instrumento utilizado foi estruturado com base nos dados do BAU.. Os resultados mostraram que a procura espontânea foi feita por mulheres jovens (14 aos 54 anos) dos bairros próximos à UER, durante a semana e no horário das sete às dezenove horas. As queixas mais frequentes foram: cefaleia, lombalgia, dores (abdominal, torácica). Conclui-se que o perfil da amostra foi, na maioria, composta por adulto jovem, idade produtiva, sexo feminino, demanda espontânea e no período diurno em dias úteis. Os atendimentos apontaram para queixas de baixa complexidade.

Descritores: Serviços Médicos de Emergência; Perfil de Saúde; Enfermagem em Emergência.

\section{Perfil de la población atendida en una unidad de emergencia de referencia}

El objetivo del estudio fue identificar el perfil sociodemográfico y las principales quejas de la población adulta atendida en la Unidad de Emergencia de Referencia (UER). El conocimiento de las características de la población que frecuenta un servicio de emergencia constituye una herramienta de planificación de las acciones en salud. Se trata de un estudio descriptivo/retrospectivo desarrollado en la UER de un hospital de enseñanza en el interior del estado de Sao Paulo. La muestra fue constituida por los boletines de atención(BAU) del período de enero a diciembre de 2.008. El instrumento utilizado fue estructurado con base en los datos del BAU. La búsqueda espontánea fue hecha por mujeres jóvenes (14 a 54 años) de los barrios próximos a la UER durante la semana y en el horario de las siete a las diecinueve horas. Las quejas más frecuentes fueron: cefalea, lumbago, dolores (abdominal, torácica). Se concluye que el perfil de la muestra fue en su mayoría adulto y joven, en edad productiva, de sexo femenino, con demanda espontánea y en el período diurno en días útiles. Las atenciones apuntaron para quejas de baja complejidad.

Descriptores: Servicios Médicos de Urgencia; Perfil de Salud; Enfermería de Urgencia.

\section{Introduction}

The situation of emergency services is currently a concern for the health community and society in general because their use has increased in recent years ${ }^{(1)}$; there are only 185 hospitals with an urgent and emergency profile ${ }^{(2-3)}$.

Health emergencies are situations in which care cannot be postponed, but has to be immediately delivered. Urgent situations are those in which care can be delivered within two hours. Finally, non-urgent situations are defined as those that can be sent to an outpatient clinic ${ }^{(4-5)}$.

One of the explanations presented for the excessive demand of urgent/emergency hospital services is that most care procedures are directed to 'simple' problems 
that could be cared for in primary or specialized health care units or in urgent services of lesser complexity. This demand profile is one of the main entrance doors to the health system and possibly reveals, among other things, an unequal distribution of the supply of services not only from the quantitative point of view but also the qualitative point of view, both in the primary, specialized and also hospital care(6). In this context, the Brazilian Single Health System (SUS) created the National Policy of Humanization (NPH) called 'Humaniza SUS', the central principles of which are to receive individuals in the service, evaluating and classifying them by risk, which is an intervention potentially decisive in the reorganization of the service network and its health promotion $^{(7)}$. A higher demand for clinical emergency services has been observed in France. These services have functioned as a source of primary care for many patients ${ }^{(8)}$. The proportion of non-urgent care delivered in emergency care units in the French pediatric sector is about $28 \%$ to $76 \%$; approximately $40 \%$ of the care provided in emergency care units to adult individuals is not urgent. This proportion is about $5 \%$ to $82 \%$ in the United States ${ }^{(9)}$.

There is not an epidemiological information system in Brazil related to emergency care, though it is provided in the National Policy of Guidelines to Reduce Morbidity and Mortality due to Accidents and Violence, approved in 2001. This guideline aims to monitor events caused by accidents and violence in addition to knowledge concerning the profile of care provided in emergency services $^{(10)}$.

In the unit investigated in this study, the initial care provided to patients is performed by nurses who check vital signs, verify their main complaints, evaluate risk factors and perform physical assessments. Whenever possible, nurses also evaluate potential risk of death and/ or complications of patients in their current state and classify them according to priority of care. The patients are classified by color: red (there is imminent risk of death and the patient is immediately sent to the emergency room); yellow (the patient should be cared for as soon as possible, though there is no eminent risk of death); green (the patient is not at risk but there is a complaint that should be heeded with appropriate priority); and blue (cases that should be cared for in primary health units). However, there is no protocol to evaluate and classify risks and after the nurses' evaluation, patients wait to be called by a physician according to the nurses' classification. Identifying the characteristics of the population who seek an emergency service is essential to plan health actions because it enables managers to reduce overcrowding in the services and allows health professionals to offer safer care to this population.

\section{Objectives}

To identify the socio-demographic profile of the adult population cared for in the Referral Emergency Care Unit of a university hospital. To identify the main complaints of the adult population cared for in this unit.

\section{Participants and method}

This is a descriptive and retrospective study with quantitative approach developed in a Referral Emergency Care Unit (RECU) of a university hospital in the interior of São Paulo. This is a large hospital that provides tertiary and quaternary care and has 403 beds $^{(11)}$. All the care delivered in this hospital is fully paid for by the Brazilian Single Health System (SUS). The RECU cares for approximately 400 patients a day; has eight beds for intensive care patients and four for orthopedic patients; and also cares for those awaiting beds for hospitalization.

The studied population was the adult patients cared for in the unit between January $1^{\text {st }}$ and December $31^{\text {st }}$ 2008. The sample was composed of care forms randomly drawn from the SAS program; totaling 300 forms a month. Data were collected by two researchers using an instrument based on the data presented in the RECU care forms.

The instrument addresses information that enables one to identify and characterize users in sociodemographic terms and also identify their complaints. It comprises the following items: the individuals' initials, hospital registration number, origin, gender and age. The following questions were included to identify the profile of health complaints manifested by the population: main complaint that led the individual to seek emergency service; history (previous diseases) that might have influenced the current problem; and vital signs at the moment of the nursing consultation. After the Research Ethics Committee (protocol no 1114/2008) approved the project, a database was developed in Excel (Windows) according to the number obtained in the draw. Data were descriptively analyzed using the SAS System for Windows (Statistical Analysis System) version 6.12, the SAS Institute Inc, 1989-1996, Cary, NC, USA. The times of consultations were classified according to the employers' schedules. The results were presented in tables and charts with support from the statistical service from the university. 


\section{Results}

Only 3,424 of the 3,600 care forms that composed the sample at the start were analyzed because 176 forms were not appropriately completed. The patients cared for in the studied period were $53.7 \%$ women and $46.3 \%$ men; the average age was 41.6 years ( $S D \pm 34.6)$, minimum 14 years old and maximum 94 years old. However, $75.5 \%$ of the forms corresponded to individuals between 14 and 54 years of age (Table 1 ).

Table 1 - List of the surveyed individuals by age and gender

\begin{tabular}{ccccccc}
\hline \multirow{2}{*}{$\begin{array}{c}\text { Age range } \\
\text { (years) }\end{array}$} & \multicolumn{2}{c}{ Female } & & \multicolumn{2}{c}{ Male } & $\begin{array}{c}\text { Consulted } \\
\text { forms }\end{array}$ \\
\cline { 2 - 3 } & $\mathbf{N}$ & $\%$ & & $\mathbf{n}$ & $\%$ & \\
\hline $14-24$ & 418 & 57.8 & & 305 & 42.2 & 723 \\
$25-34$ & 375 & 51.1 & & 360 & 48.9 & 735 \\
$35-44$ & 320 & 53.8 & & 274 & 46.2 & 594 \\
$45-54$ & 298 & 55.8 & & 236 & 44.2 & 534 \\
$55-64$ & 204 & 53.2 & & 180 & 46.8 & 384 \\
$65-74$ & 130 & 46.7 & & 148 & 53.2 & 278 \\
$75-84$ & 82 & 58.2 & & 59 & 41.8 & 141 \\
$85-94$ & 20 & 57.2 & & 15 & 42.8 & 35 \\
Total & & & & & & 3,424 \\
\end{tabular}

A total of $95.35 \%$ of the individuals spontaneously sought the emergency unit; $74.8 \%$ were from the city itself, while $4.3 \%$ were from the neighborhoods Barão Geraldo and Cidade Universitária, 2.6\% originated from downtown and another $2.6 \%$ from Parque São Quirino, the neighborhoods with the largest demand. Other neighborhoods provided smaller individual percentages, but gathered into one group, they represent $84.57 \%$ of the demand. Weekdays presented a balanced distribution in relation to the number of individuals consulted and demand was higher at the beginning of the week: Monday 579 (17\%), Tuesday 578 (16\%), Wednesday 513 (15\%), Thursday 489 (14\%), Friday $487(12 \%)$, Saturday $417(11 \%)$ e Sunday $361(10 \%)$ (Figure 1)

The number of patients cared for in the periods classified according to the employees' schedules were: $1,150(45 \%)$ patients were cared for from 7am to $12: 59 \mathrm{pm} ; 1,157$ (34\%) were cared for $1 \mathrm{pm}$ to $6: 59 \mathrm{pm}$; $594(17 \%)$ from $7 p m$ to $11: 59 p m$; and 118 (3\%) from 12am to 6:59am.

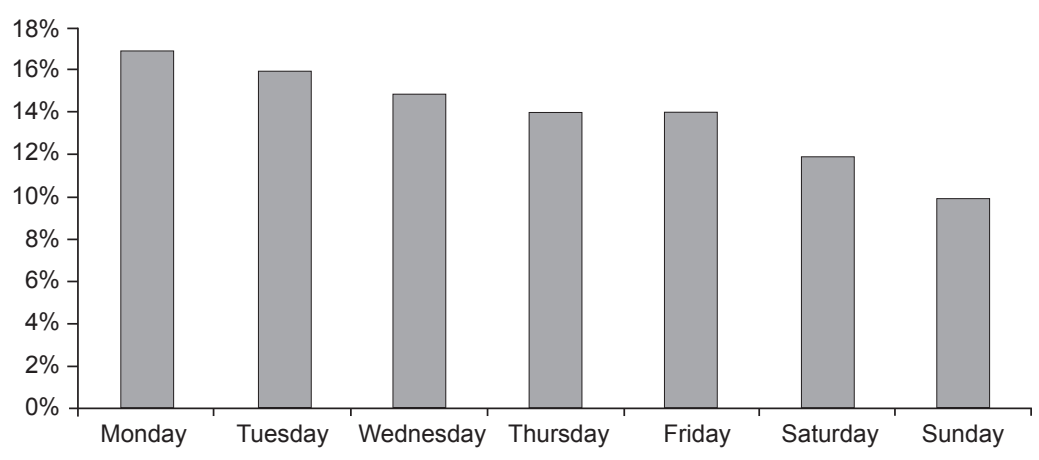

Figure 1 - Distribuition of care provided by day of the week

According to the classification of risk as categorized by nurses: 2,306 (67\%) were classified at the 'green' level of risk; 622 (18\%) at 'blue'; 409 (12\%) 'yellow'; and $87(2 \%)$ 'red'. The average time the patients reported they experienced the problem was 40 days, minimum of one day and maximum of 1,095 days.

A total of 186 different complaints were identified and the ten most frequent were: headache 316 $(9.22 \%)$, lower back pain $225(6.57 \%)$, abdominal pain $174(5.08 \%)$, chest pain $161(4.70 \%)$, pain in the lower limbs 122 (3.56\%), sore throat 109 (3.18\%), cough $104(3.03 \%)$, epigastric pain 103 (3.00\%), dyspnea 98 $(2.89 \%)$ and dysuria $79(2.30 \%)$. The main complaints were not reported in $4 \%$ (138) of the forms (Figure 2).

Complaints by season were not very diversified. In the spring the most frequent complaints were headache
$65(7.9 \%)$, chest pain, $49(6 \%)$ and 48 lower back pain (6\%). In the winter, headache $79(9.1 \%)$, cough $58(7 \%)$ and abdominal pain $50(6.1 \%)$. In the fall, headache, $102(12 \%)$, back pain $54(6.6 \%)$ and abdominal pain $39(4.7 \%)$, and in the summer, back pain $78(9.5 \%)$, headache $65(7.8 \%)$ and abdominal pain $43(5.2 \%)$.

The additional tests most requested by the medical team were: laboratory tests (blood) 260 (7.5\%), diagnostic imaging (X-ray, ultrasound and CT Scan) $216(6.3 \%)$, urinary tests, 145 (5\%), and ECGs 130 (5\%). Among the most commonly performed nursing procedures were: IV medication 1.450 (50\%), oral medication 290 (10\%), blood collection 260 (8\%), measurement of blood glucose 210 (7\%), IM medication $145(5 \%)$, SC medication $60(2 \%)$, curative $45(2 \%)$ and enema 32 (1\%) (Figure 3 ). 


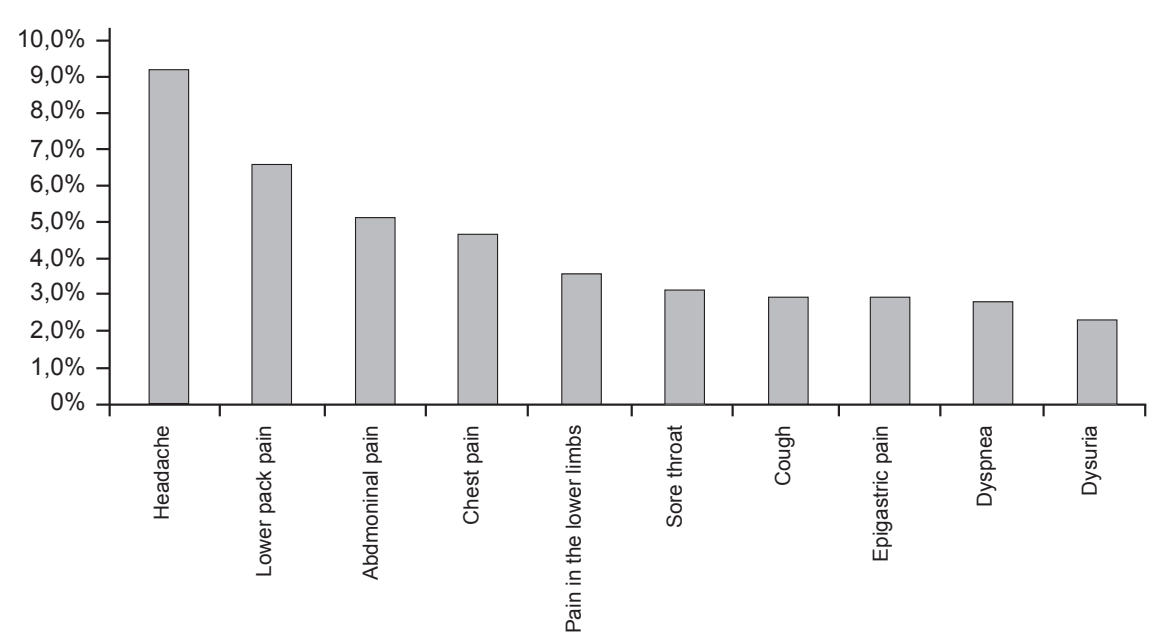

Figure 2 - Distribution of the ten most frequently complaints reported by users

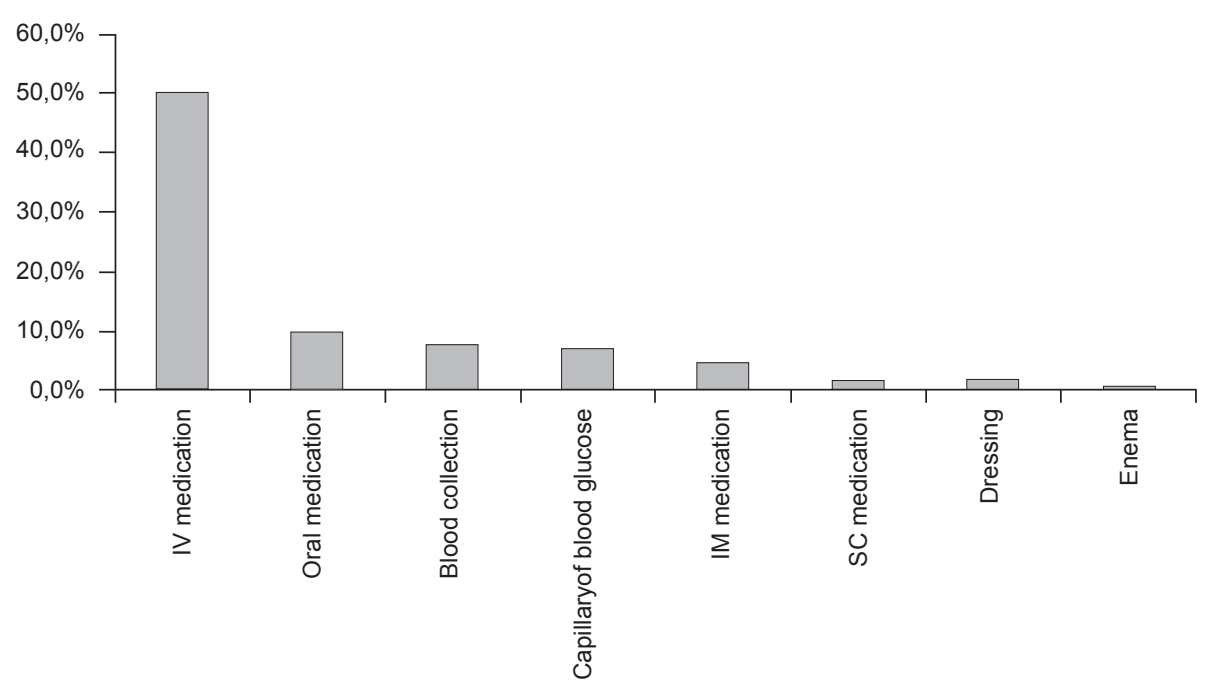

Figure 3 - Distribution of the most performed nursing procedures

A diagnostic hypothesis was not informed in 668 $(19.5 \%)$ of the analyzed care forms and those that contained such information comprised a total of 384 diagnostic hypotheses: lower back pain 137 (4\%), urinary tract infection $102(3 \%)$, upper respiratory tract infection $95(2.70 \%)$, headache $93(2.50 \%)$, acute gastroenterocolitis $83(2.4 \%)$, sinusitis $74(2.2 \%)$, tonsillitis $72(2 \%)$, dyspepsia $54(1.5 \%)$, pneumonia $54(1.4 \%)$, trauma $49(1.5 \%)$ hypertensive crisis 48 $(1.4 \%)$ and asthma 35 (1\%) (Table 2).
Table 2 - Main diagnostic hypothesis identified in the care forms

\begin{tabular}{lcc}
\hline \multicolumn{1}{c}{ Diagnostic hypotheses $(\mathbf{D H})$} & $\mathbf{n}$ & $\mathbf{( \% )}$ \\
\hline Low back pain & 137 & 4.0 \\
Urinary tract infection & 102 & 3.0 \\
Upper respiratory tract infection & 95 & 2.7 \\
Headache & 83 & 2.5 \\
Acute gastroenterocolitis & 83 & 2.5 \\
Sinusitis & 74 & 2.1 \\
Tonsillitis & 72 & 2.0 \\
Dyspepsia & 54 & 1.5 \\
Pneumonia & 54 & 1.5 \\
Trauma (not specified) & 49 & 1.4 \\
Hypertensive crisis & 48 & 1.4 \\
Asthma & 35 & 1 \\
Others & 1870 & 54.8 \\
Total & 3424 & \\
\hline
\end{tabular}


Most of the patients $(2,583 / 74.1 \%)$ were discharged after receiving care in the unit; 837 (24.4\%) pacients were referred to other services out of the unit and 10 $(0.2 \%)$ were hospitalized.

The patients' vital parameters presented great variation during the nursing consultations. The average SBP was $140 \mathrm{mmHg}(\min =70 ; \max =220)$ and the average DBP was $80 \mathrm{mmHg}(\min =40 ; \max =120)$ in the $3,186(93 \%)$ care forms that presented this information. The average heartbeat was $85 \mathrm{bpm}(\min =46 ; \max =186)$ in the $3,098(89.9 \%)$ that contained such information. A total of 318 (9.2\%) forms reported 18 breaths per minute on average $(\min =12 ; \max =32)$. The average temperature was $36.5^{\circ} \mathrm{C}(\min =33 ; \max =39.5)$ in a total of $1,306(38.1 \%)$ forms presenting this information.

The history of patients indicated there were: 248 (7.3\%) cases of diabetes mellitus; 708 (20.9\%) systemic hypertension; 177 (5.1\%) cases of cardiopathy; 27 $(0.8 \%)$ ischemic stroke; and 35 (1\%) HIV cases. There were about $6 \%$ of blank answers for each of the investigated items.

\section{Discussion}

A larger percentage of female patients were identified in the distribution of the patients cared for in the RECU by gender. This profile is similar to that indicated by DATASUS ${ }^{(12)}$ for the studied city: $50.74 \%$ women and 48.98\%; other Brazilian studies corroborate this distribution(1,13-16). Individuals between 14 and 54 years old represented $75.5 \%$ of the total individuals cared for in the unit, revealing the service is predominantly sought by young women.

The service is predominantly used by residents from the nearest neighborhoods. Some studies ${ }^{(1,13-14,17)}$ indicate that the greater demand for emergency services is related to smaller distances from home to the services in addition to the expectation of patients that they will immediately solve their problem; they expect easy and fast access and treatment. The percentage of individuals in this study who live in close proximity to the service is below $10 \%$; it is not an expressive majority and perhaps should not be considered relevant. Attention should be paid to the $74 \%$ who spontaneously seek the service. These are users from the city itself, which indicates this unit is failing to deliver care only to referred users. While the demand of male individuals for outpatient services is usually generated by occupational or social security reasons, the demand from female individuals is voluntary, which reveals the tendency of women to spontaneously seek the service ${ }^{(6,15,18)}$. Various studies show the reasons users seek urgent/emergency services and geographical accessibility is among the reasons, in addition to the general quality of care services, the service's problem solving capacity, access to medication and difficult access to consultations in the primary health care service ${ }^{(6,16,19-21)}$.

The organizational structure of non-hospital urgent and emergency units in the metropolitan region of Campinas presented diversified problems such as physical structure deficiencies, and a lack of equipment, material and medication in the different units of the studied city(21). The author asserts this can become a complex problem if appropriate treatment and care is not provided to patients within the primary health care scope; medical units with low problem-solving capacity lead users to directly seek hospitals to solve their health problems.

The days of the week with the highest number of patients were Mondays and Tuesdays, with the heaviest volume of consultations in the morning (45\%) followed by the afternoon (34\%). These periods with the highest number of consultations correspond to the primary health care units' open hours, therefore these should, a priori, absorb such demand(6,15). These findings corroborate national ${ }^{(1,6,14)}$ and international ${ }^{(17)}$ studies that point out that a higher demand is observed in the daytime period. Even though health units are open during the day, the hospital-centered model is still current in Brazil. Nevertheless, reflections upon transformations that occurred in the health care model are enabling the replacement of this model by the family health program(22).

Classification of risk is an exclusive task of nurses, who should be qualified and competent in the recognition of signs and symptoms that indicate a severe condition when a patient arrives at the emergency unit. There are no studies in the literature comparing the classification performed by nurses in relation to the colors red, yellow, green and blue. This study indicates that nurses rated $67 \%$ of patients in green, which may represent either the true demand of the studied unit or a false positive, because there is no risk assessment protocol in place yet. This fact allows for subjective interpretations of the users' complaints on the part of the professionals who assess patients.

Among the 186 most frequent complaints reported by patients were: headache, lower back pain, abdominal pain, chest pain, and pain in the lower limbs. These findings are similar to those obtained in 
other studies ${ }^{(1,6,14,16)}$, highlighting a study carried out in the south of Brazil(1,23) that shows that symptoms of chronic diseases were present in emergency units. It indicates that non-emergency cases very frequently seek the emergency unit to solve a situation that could be resolved during an outpatient follow-up. The study also reveals that seasonality did not affect the types of complaints.

The most frequent diagnostic hypotheses such as lower back pain, urinary tract infection, infection of the upper airways, headache, acute gastroenterecolitis, among others, presented behavior similar to other national studies ${ }^{(1,14-16)}$. The authors of another study ${ }^{(14)}$ related diagnostic hypotheses with peak periods such as the population's higher mobility during schools breaks and carnivals with consequent changes in eating habits that cause gastroenteritis, headaches, and viral infections. According to the study's authors, data analysis was only possible with the creation of a computer database.

During this study's data collection, we verified that a digital database is not available and incorrect filling, illegible writing or incomplete data hindered, in part, data analysis. The second leading cause of high demand verified in another study ${ }^{(6)}$ was respiratory diseases followed by digestive diseases, which portrays poverty and health conditions as limiting factors of health in general in the Northeast population. The complementary exams most required by the medical team were laboratory exams (blood), diagnostic imaging, urine tests and EECs. Some of them are also verified in other Brazilian studies ${ }^{(1,13-14)}$, which highlights the importance of primary health care units having the problem-solving capacity to absorb the demand of complementary exams such as uriny, blood, and EEC exams.

The most frequent nursing procedures included those of low complextiy involving the administration of medications by different routes, blood collection, and blood glucose monitoring. No studies relating nursing procedures to the workload of nursing professionals in emergency units were found. The discharge of most patients after consultation indicates that individuals did not present severe conditions despite variations in vital parameters found during risk assessment; a similar situation is reported in national studies conducted in large capitals such as São Paulo and Florianopolis e Salvador ${ }^{(1,14,16)}$.

The conclusion is that this demand could be absorbed by the primary health care unit in the area for nearby users. The population needs to be informed about the correct use of services available in the city. A similar phenomenon occurs with urgent units of lower complexity. These are underused by those individuals who could be treated and handled in primary health care units $^{(21,24-25)}$. As already noted by another author ${ }^{(22)}$, the easy access to medication and solutions for less severe health problems available in emergency departments leads individuals to seek these services even when not necessary. Perhaps, there are different perceptions between health professionals and users in relation to the terms 'urgent' and 'emergency'.

From this perspective, it would be interesting for hospitals (emergency departments), non-hospital urgent and emergency units and primary health care units to collaborate strategically which each other in order to invert this flow. The system's "entrance door" should be the primary health care units and only referrals should be cared for in emergency units, according to a case's complexity.

A recent Brazilian bibliographic review(2) reports that international studies investigating interventions in emergency units on overcrowding are inconsistent because these studies are not experimental but observational and use simple designs such as before and after interventions, which allows for biases. The conclusion is that the issue of overcrowding in emergency departments should be on the public health agenda since there is an insufficient number of theses and dissertations addressing the theme.

\section{Conclusion}

The profile of the sample cared for in the RECU was female young adults of productive age, residents in the city itself, who spontaneously sought the service on weekdays during the day. The consultations were directed to complaints of low complexity, which according to the risk assessment, resulted in: $67 \%$ green, $18 \%$ blue, $12 \%$ yellow and $2 \%$ red catagorizations. Complaints were diversified in the category 'green' (present no risks though it should be heeded with apropriate priority) each presenting a percentage below $10 \%$ such as: headaches, lower back pain, abdomincal pain and chest pain, among others. Complaints were not related to seasonality. The results indicate a demand that is inconsistent with the size of a referral emergency unit; that is, the population underestimates the demand. 


\section{References}

1. Silva VPM, Silva AK, Heinisch RH, Heinisch LMM. Caracterização do Perfil da Demanda da Emergência de Clínica Médica do Hospital Universitário da Universidade Federal de Santa Catarina. Arq Catarin Med. 2007;36(4):18-25.

2. Bittencourt RJ, Hortale VA. Intervenções para solucionar a superlotação em emergência hospitalar. Cad Saúde Pública. 2009; 25(7):1439-54.

3. Sá DA. Proposta metodológica para classificação dos hospitais de urgência/emergência do SUS. Brasília: Secretaria Executiva, Ministério da Saúde; 2005.

4. Goldim JR. Introdução a bioética [internet]. Rio Grande do Sul; 2009[acesso 10 ago 2009]. Disponível em: www.hcpa.ufrg.br/bioeticaf.html.

5. Schiavon ICA. A triagem em serviço de emergência [dissertação de mestrado]. Campinas (SP): Faculdade de Ciências Médicas da Universidade Estadual de Campinas; 2006. 84 p.

6. Simons DA. Avaliação do perfil da demanda na unidade de emergência em Alagoas a partir da municipalização da saúde e do programa Saúde da Família. [tese de doutorado]. Recife (PE): Fundação Osvaldo Cruz- Centro de Pesquisa Aggeu Magalhães; 2008.161 p.

7. Ministério da Saúde (BR). Secretaria Executiva. Núcleo Técnico da Política nacional de Humanização. HumanizaSUS. Acolhimento com Avaliação e Classificação de Risco: um paradigma ético-estético no fazer em saúde. Brasília; 2002

8. Lang T, David A, Diakité B, Agay E, Viel JF, Flicoteaux $B$. Using the hospital emergency department as a regular source of care. Eur J Epidemiol. 1997;13:223-8.

9. Lang $T$, David A, Diakité B, Agay E, Viel JF, Flicoteaux B. Non-urgent care in the hospital medical emergency department in France: how much and which health needs does it reflect?.J Epidemiol Commun Health. $1996 ; 50: 456-62$.

10. Calil AM. O enfermeiro e as situações de emergência. São Paulo: Atheneu; 2007. 795 p.

11. Hospital das Clínicas Unicamp [internet]. Campinas: HC/UNICAMP; 2009 [acesso 20 ago 2009]. Disponível em: http://www.hc.unicamp.br/instalacoes/instalacoes.shtml

12. Prefeitura Municipal de Campinas [internet]. Campinas; 2009 [acesso 17 set 2009]. Disponível em: http://www.campinas.sp.gov.br/saude
13. Furtado BMASM, Araújo JLC Júnior, Cavalcanti P. O perfil da emergência do Hospital da Restauração: uma análise dos possíveis impactos após a municipalização dos serviços de saúde. Rev Bras Epidemiol. 2004; 7(3):279-89.

14. Jacobs PC, Matos EP. Estudo Exploratório dos Atendimentos em Unidade de Emergência em Salvador Bahia. Rev Assoc Med Bras. 2005;51(6):348-53.

15. Universidade de São Paulo (SP). Projeto "avaliação sociais de saúde OSS /São Paulo: Estudo do perfil da demanda do serviço de pronto socorro do hospital geral de Itaquaquecetuba: : Relatório Final. São Paulo (SP): Convênio SES - SP/USP-FSP; 2002. 64 p.

16. Barakat SFC. Caracterização da demanda do Serviço de Emergências Clínicas de um hospital terciário do município de São Paulo [tese de doutorado]. São Paulo (SP): Faculdade de Medicina da Universidade de São Paulo; 2004. $120 \mathrm{p}$

17. Fajardo-Ortiz G, Ramírez-Fernández FA. Utilización del servicio de urgencias en un hospital de especialidades. Cir Cir. 2000;68(4):164-8.

18. Aquino EML, Menezes GMS, Amoedo MB. Gênero e saúde no Brasil: considerações a partir da Pesquisa Nacional por Amostra de Domicílios. Rev Saúde Pública. 1992;26(3):195-202.

19. Aranaz AJM, Nogueras RM, Castro MTGV, Bartual VR, Garcia PA, Pajares FG. Por qué los pacientes utilizan los servicios de urgencias hospitalarios por iniciativa propia? Gac Sanit. 2006;20(4):311-5.

20. Felisberto E, Leal C, Samico IC. Referencia na atenção pediátrica: uma"emergência" em Pernambuco. Rev Bras Saúde Materno Infantil. 1994;9:61-9.

21. Almeida AO. Unidades não hospitalares de atendimento à urgência e emergência da Região Metropolitana de Campinas: aspectos organizacionais e conhecimento teórico dos enfermeiros sobre PCR/RCP. [dissertação de mestrado] Campinas (SP): Faculdade de Ciências Médicas da Universidade Estadual de Campinas: 2008. 144 p.

22. Rosa WAG, Labate RC. Programa Saúde da Família: A construção de um novo modelo de assistência. Rev. Latino-Am. Enfemagem. 2005;13(6):1027-34.

23. Baker K. Review Article Chronic pain syndromes in the emergency department: Identifying guidelines for management. Emerg Med Austr. 2005;17(1):57-63. 
24. Santos JS, Scarpelini S, Brasileiro SLL, Ferraz

CA, Dallora MELV, Sá MFS. Avaliação do modelo de organização da Unidade de Emergência do HCFMRPUSP, adotando, como referência, as políticas nacionais de atenção às urgências e de humanização. Medicina. 2003;36:498-515.

25. Rocha AFS. Determinantes da procura de atendimento de urgência pelos usuários nas unidades de pronto atendimento da secretaria municipal de saúde de Belo Horizonte. [dissertação de mestrado]. Belo Horizonte (MG): Universidade Federal de Minas Gerais; 2005. 120 p. 